\title{
Bioaccumulation of heavy metals in Spinacea oleracea grown in distillery effluent irrigated soil
}

\author{
Chakresh Pathak*, A. K. Chopra, Ashutosh Gautam ${ }^{1}$ and Sachin Srivastava \\ Department of Zoology and Environmental Science, Gurukula Kangri University, Haridwar-249404 (Uttarakhand), \\ INDIA \\ ${ }^{1}$ Environment Management Divison, India Glycols Limited, Kashipur (Uttarakhand), INDIA \\ *Corresponding author: chakreshpathak@yahoo.co.in
}

Received: October 18, 2014 Revised received: December 01, 2014 Accepted: December 10, 2014

\begin{abstract}
The aim of the present study was to estimate the accumulation of heavy metals in Spinacea oleracea plant grown in Distillery Effluent (DE) irrigated soil. The results revealed that there was an increase in the metal contents $\mathrm{Fe}(+2.39 \%), \mathrm{Zn}(+14.27 \%)$, Ni $(+70.45 \%)$, Cd $(+34.15 \%)$ and $\mathrm{Cr}(+20.46 \%)$ of soil irrigated with $\mathrm{DE}$. In case of $S$. oleracea grown in the DE irrigated soil, it was observed that there was maximum concentration of $\mathrm{Fe}$ $(353.24 \pm 7.94 \mathrm{mg} / \mathrm{kg})$ and $\mathrm{Zn}(78.95 \pm 7.59 \mathrm{mg} / \mathrm{kg})$ in leaves and that of $\mathrm{Cr}(54.19 \pm 8.39 \mathrm{mg} / \mathrm{kg}), \mathrm{Cd}(7.73 \pm 1.41 \mathrm{mg} / \mathrm{kg})$ and $\mathrm{Ni}(66.47 \pm 3.65 \mathrm{mg} / \mathrm{kg})$ in root. The value of Bio-concentration factor (BCF) was found maximum for $\mathrm{Cr}(2.00)$ in comparison to other metals in the $S$. oleracea irrigated with DE. The value of Transfer factor (TF) was found maximum for Zn (TF- 1.51) for the soil irrigated with DE in comparison to soil irrigated with Bore well water (BWW). The DE can be a source of contamination to the soil as some toxic metals may also be transferred to roots and then to leaves in S. oleracea. The practice of continuous irrigation of agricultural land by DE may increase the risk of metal contamination in growing food crops to cause human health risks.
\end{abstract}

Keywords: Bio-concentration factor, Distillery effluent, Heavy metals, Spinacea oleracea, Transfer factor

\section{INTRODUCTION}

The occurrence of heavy metals in the environment and foodstuff represents a critical problem in all over world. Heavy metals in waste water come from industries and municipal sewage and are one of the main causes of water and soil pollution. The discharge of heavy metals as a byproduct of various human activities has been accompanied by large scale soil pollution. So much so that contamination levels in these soils were either more than normal levels or expected to soon reach those levels (Yargholi et al., 2008). Long-term use of irrigation on agricultural lands contributes significantly to the buildup of the elevated levels of these metals in soils and plants (Nyamangara and Mzezewa, 1999, Mapanda et al., 2005 and Sharma et al., 2007) which is of serious concern.

The mobility of heavy metals, their bioavailability and related eco-toxicology to plants depend strongly on their specific chemical forms or ways of bindings. Metal chemistry, speciation and thus bioavailability are known to be dependent on soil physicochemical parameters. Strong binding of heavy metals to the soil particles reduces the bioavailability resulting in less plant uptake. Soil erosion and plant uptake are the ways for loss of metals from soil. Still, heavy metals are considered to be less mobile and thus less bioavilable in soil rich in organic matter and clay contents (Jagtap et al., 2010). Most heavy metals infiltrate and accumulate in the top soil. Accumulation of heavy metals in soil is incremental and in the long term results in increased levels of contamination so much so that contamination levels may reach limits that can constitute a real threat to food safety for human civilization. The risk associated with the exposure to trace metals in food products has aroused widespread concern in human health. Acute and chronic symptoms, dizziness, nausea, vomiting, diarrhea, sleeping disorders, loss of appetite and reduced conception rate are the symptoms of heavy metal toxicity. These metals are also connected to cardiovascular disease, depressed growth, impaired fertility, nervous and immune system disorders, increased spontaneous abortions and elevated death rate among infants (Yuzbas et al., 2003 and Bakircioglu et al., 2011).

In many developing countries including India, farmers are irrigating their crop plants with industrial effluents having high level of several toxic metals $(\mathrm{Cu}, \mathrm{Cd}, \mathrm{Cr}$, $\mathrm{Zn}, \mathrm{Fe}, \mathrm{Ni}, \mathrm{Mn}$ and $\mathrm{Pb}$ ) due to the non-availability of alternative sources of irrigation water (Chandra et al., 2009).The distilleries and breweries are considered as a major polluter of the environment. Distilleries are one of the 17 most polluting industries listed by the 
Central Pollution Control Board (Singh and Yadav, 2012). At present, there are 319 distilleries in India with an installed capacity of 3.29 billion litre of alcohol (Malaviyaand Sharma, 2011). In addition, the distillery effluent is characterized by high biochemical oxygen demand (BOD), chemical oxygen demand (COD), phenolic compounds, sulphate and heavy metals (Pant and Adholeya, 2007).

Spinacea oleracea (Spinach) is an edible flowering plant in the family of Amaranthaceae. It is a cool season crop that is easily grown here through winter and in early spring. It is a leafy vegetable and it had greater potential of accumulating heavy metals in their edible parts than grain or fruit crops and has hypoglycemic properties. The leaves are cooling, emollient, antipyretic, diuretic, maturant, laxative, digestible, anthelmintic, useful in urinary concretion, inflammation of the lungs and the bowels, sore throat, pain in joints, thirst, lumbago, cold and sneezing, sore eye, ring worm, scabies, leucoderma, soalding urine, arrest vomiting, biliousness, flatulence and have been used in the treatment of febrile conditions (Subhash et al., 2010).

Keeping in view of the medical importance of $S$. oleracea, the present study was undertaken to observe the bioaccumulation of heavy metals in $\mathrm{S}$. oleracea grown in Distillery effluent (DE) irrigated soil.

\section{MATERIALS AND METHODS}

Experimental design: The present field study was conducted in the experimental garden of the Department of Zoology and Environmental Sciences, Gurukula Kangri University, Haridwar (29 55'10.81" $\mathrm{N}$ and $78^{\circ} 07^{\prime} 08.12^{\prime \prime}$ E) during the period November, 2008February, 2009 to study the evaluation of selected heavy metals level in $S$. oleracea grown in DE irrigated soil with Bore well water (BWW) taken as control. Twelve microplots (each of diameter. $30 \mathrm{~cm}$ ) were used for growing the $S$. oleracea. The experiments were conducted under completely randomized design and were replicated six times.

Soil analysis: The soil was analyzed after harvesting the crop for the physico-chemical parameters such as soil $\mathrm{pH}$ and Electrical conductivity (EC) were determined at soil/water ratio of 1:1 using glass electrode $\mathrm{pH}$ meter and EC meter, Organic carbon (OC), Total Kjeldahl Nitrogen (TKN), Available Phosphorous (P), Available Potassium (K) and heavy metals $(\mathrm{Zn}, \mathrm{Fe}, \mathrm{Ni}, \mathrm{Cr}$ and $\mathrm{Cd})$ were determined as per standard methods (APHA, 2005; Chaturvedi and Sankar, 2006).

The soil samples as well as the leaves and roots of $S$. oleracea were dried separately in air at room temperature and sieved through a $2 \mathrm{~mm}$ sieve. Samples were digested in Nitric acid $\left(\mathrm{HNO}_{3}\right)$ and Perchloric acid $\left(\mathrm{HClO}_{4}\right)$ acid as per the method described in AOAC (Association of Official Analytical Chemists, 1990). After digestion, all samples were filtered through
Whatmann No. 42 filter paper and in each case volume was made with $50 \mathrm{ml}$. Heavy metals such as Zinc (Zn), Iron (Fe), Nickel (Ni), Chromium (Cr) and Cadmium (Cd) were determined in the digested aliquot by Atomic Absorption Spectrophotometer (AAS) (MakeECIL, Model No. 4129) using a specific lamp of particular metal using appropriate drift blank.

Data analysis: The heavy metal contents in both the $S$. oleracea and adjoining soil were expressed as means and standard deviation of six replicates calculated in Microsoft Office Excel (2007) and Axum 50.

Bio-concentration factor (BCF): The BCF for $S$. oleracea for all metal is expressed by the following formula:

$\mathrm{BCF}=\mathrm{C}_{\mathrm{M}} / \mathrm{C}_{\mathrm{S}}$

where BCF represents the bioaccumulation factor of $S$. oleracea; $\mathrm{C}_{\mathrm{M}}$ is the metal concentration in $S$. oleracea root and $\mathrm{C}_{\mathrm{S}}$ is the metal content of growth media (soil) (Yoon et al., 2006).

Transfer factor (TF): TF was calculated for the amount of threat and associated exposure due to waste water irrigation and resulting heavy metal accumulation in edible portion of test vegetables. It was calculated following the formula given by (Cui et al., 2004, Singh et al., 2010).

\section{RESULTS AND DISCUSSION}

Physico-chemical characteristics and heavy metal contents of soil after irrigation: The mean $\pm \mathrm{SD}$ of variousphysico-chemical parameters viz. $\mathrm{pH}, \mathrm{EC}, \mathrm{OC}$, TKN, K, P and heavy metals contents in soil after irrigation with $100 \%$ concentration of DE irrigated soil and with BWW irrigated soil for 60 days harvesting are given in Table 1.

The industrial effluents play an important role in altering the physico-chemical characteristics and heavy metal contents of soil.The long-term application of DE has been proved useful in significantly increasing OC, TKN, K, P and enzymatic activities in the soil but tended to build up harmful concentration of sodium that could be chelated by bioamendments. Short-term application of $50 \%$ DE along with bioamendments proved to be the most useful in improving the properties of sodic soil (Kaushik et al., 2005). Effluent irrigation generally adds significant quantities of salts to the soil environment such as sulfates, phosphates, bicarbonates, chlorides of the cations sodium, calcium, potassium and magnesium that stimulate the growth at lower concentration but inhibit at higher concentration (Patterson et al., 2008).It has been reported reported that DE (spent wash) discharged as wastewater contains various nutrients and toxic chemicals that can contaminate water and soil which may affect the common crops if used for agricultural irrigation (Kannan and Upreti, 2008).

In the present study, the soil characteristics have been found to change on irrigation with $100 \%$ concentration of DE after 60 days of $S$. oleracea crop harvesting. The 
Table 1. Physico-chemical properties and heavy metal contents in soil after irrigation with BWW (control) and DE irrigated

\begin{tabular}{llcccc}
\hline S.No. & Parameters & $\begin{array}{c}\text { BWW } \\
\text { irrigated }\end{array}$ & $\begin{array}{c}\text { DE } \\
\text { irrigated }\end{array}$ & $\begin{array}{c}\text { Permissible } \\
\text { limit(a) }\end{array}$ & $\begin{array}{c}\text { Permissible } \\
\text { limit(b) }\end{array}$ \\
\hline 1 & $\mathrm{pH}$ & $8.05 \pm 0.06$ & $7.75 \pm 0.06(-3.87 \%)$ & - & - \\
2 & $\mathrm{EC}\left(\mathrm{dsm}^{-1}\right)$ & $0.14 \pm 0.06$ & $0.72 \pm 0.37 *(+80.55 \%)$ & - & - \\
3 & $\mathrm{OC} \%$ & $0.80 \pm 0.14$ & $1.20 \pm 0.47(+33.33 \%)$ & - & - \\
4 & $\mathrm{~K}(\mathrm{mg} / \mathrm{kg})$ & $130.75 \pm 10.44$ & $583 \pm 13.88 *(+77.57 \%)$ & - & - \\
5 & $\mathrm{~N}(\mathrm{mg} / \mathrm{kg})$ & $1.82 \pm 0.17$ & $2.41 \pm 0.15^{*}(+24.48 \%)$ & - & - \\
6 & $\mathrm{P}(\mathrm{mg} / \mathrm{kg})$ & $57.66 \pm 5.60$ & $93.53 \pm 6.16 *(+38.35 \%)$ & - & 300 \\
7 & $\mathrm{Zn}(\mathrm{mg} / \mathrm{kg})$ & $43.44 \pm 4.26$ & $52.17 \pm 4.73 *(+16.73 \%)$ & $300-600$ & 1,000 \\
8 & $\mathrm{Fe}(\mathrm{mg} / \mathrm{kg})$ & $177.49 \pm 6.71$ & $287.82 \pm 7.84 *(+38.33 \%)$ & - & 60 \\
9 & $\mathrm{Ni}(\mathrm{mg} / \mathrm{kg})$ & $63.02 \pm 6.07$ & $206.51 \pm 9.63 *(+69.48 \%)$ & $75-150$ & $\mathrm{NA}$ \\
10 & $\mathrm{Cr}(\mathrm{mg} / \mathrm{kg})$ & $18.53 \pm 2.89$ & $27.03 \pm 5.90(+31.45 \%)$ & $3-6$ & 50 \\
11 & $\mathrm{Cd}(\mathrm{mg} / \mathrm{kg})$ & $6.49 \pm 1.88$ & $8.45 \pm 2.57(+23.20 \%)$ & & 1 \\
\hline
\end{tabular}

(a) Source: Awashthi (2000), (b) Source: Kabata-Pendias and Pendias (1992), *indicates significant increase $(\mathrm{P}<0.05)$.

irrigation with $100 \%$ concentration of DE significantly increased the EC $(+431.99 \%), \mathrm{K}(+345.89 \%)$, TKN $(+32.28 \%)$ and $\mathrm{P}(+62.22 \%)$ and there was a slight decrease of $\mathrm{pH}(-3.87 \%)$ in comparison to BWW irrigated soil. Kumar and Chopra (2012) also observed significant increase in the EC $(84.13 \%), \mathrm{K}^{+}(31.59 \%)$ and TKN (1723.32\%) after irrigation of soil with $100 \%$ distillery effluent concentration upto 90 days for Trigonellafoenum-graecum, while Srivastavaet al. (2012) observed significant increase in the EC $(+63.46 \%)$, OC $(+3746.63 \%), \mathrm{K}(+48.39 \%)$, TKN $(+1449.18 \%), \mathrm{P}(+338.83 \%)$ in soil irrigated with distillery effluent after 60 days of irrigation for Abelmoschus esculentus. $\mathrm{pH}$ is an important parameter as many nutrients are available only at a particular range of $\mathrm{pH}$ for plant uptake (Kumar and Chopra, 2011). Under acidic conditions, elements such as Fe, $\mathrm{Al}, \mathrm{Mn}$, and heavy metals $(\mathrm{Zn}, \mathrm{Cu}$ and $\mathrm{Cr}$ ) become highly soluble and may create problems for vegetation (Charman and Murphy, 1991).

Among various metals, the concentrations of $\mathrm{Zn}$ $(52.17 \pm 4.73 \mathrm{mg} / \mathrm{kg}), \mathrm{Fe}(287.82 \pm 7.84 \mathrm{mg} / \mathrm{kg})$ and $\mathrm{Cr}$ $(27.03 \pm 5.90 \mathrm{mg} / \mathrm{kg})$ in DE irrigated soil were below the official Indian Standard (Awashthi, 2000; KabataPendias and Pendias, 1992), whereas Ni (206.51 \pm 9.63 $\mathrm{mg} / \mathrm{kg})$ and $\mathrm{Cd}(8.45 \pm 2.57 \mathrm{mg} / \mathrm{kg})$ concentrations in DE irrigated soil were several folds higher than the permissible limits official Indian Standard as cited in Awashthi (2000) and Kabata-Pendias and Pendias (1992).

The study revealed that the level of heavy metals ( $\mathrm{Zn}$ $52.17 \pm 4.73 \mathrm{mg} / \mathrm{kg}, \quad \mathrm{Fe}-287.82 \pm 7.84 \mathrm{mg} / \mathrm{kg}, \quad \mathrm{Ni}-$ $206.51 \pm 9.63 \mathrm{mg} / \mathrm{kg}, \mathrm{Cr}-27.03 \pm 5.90 \mathrm{mg} / \mathrm{kg}$ and $\mathrm{Cd}-$ $8.45 \pm 2.57 \mathrm{mg} / \mathrm{kg}$ ) in soil irrigated with DE were observed to be higher than the values reported by
Kumar and Chopra (2011) for Zn-8.86 $\pm 0.26 \mathrm{mg} / \mathrm{kg}$, $\mathrm{Fe}-10.67 \pm 2.21 \mathrm{mg} / \mathrm{kg}, \mathrm{Cr}-1.98 \pm 0.07 \mathrm{mg} / \mathrm{kg}$ and Cd$0.94 \pm 0.02 \mathrm{mg} / \mathrm{kgin}$ DE irrigated soil atHaridwar, while the present values were lower than the values reported by Gupta et al. (2007) for Fe-20,401.3 mg/kg, Zn$230.8 \mathrm{mg} / \mathrm{kg}, \mathrm{Cr}-293.7 \mathrm{mg} / \mathrm{kg}$ and $\mathrm{Ni}-26.9 \mathrm{mg} / \mathrm{kg}$ in tannery waste water irrigated soil. Similarly, Chandraju et al. (2010) observed lower concentration of DTPA Fe $-240.0 \mathrm{mg} / \mathrm{kg}$ and higher concentration of DTPA Zn - $65.0 \mathrm{mg} / \mathrm{kg}$ in soil irrigated Distillery spent wash for 30 days as compared to the concentration of Fe $(287.82 \pm 7.84 \mathrm{mg} / \mathrm{kg})$ and $\mathrm{Zn}(52.17 \pm 4.73 \mathrm{mg} / \mathrm{kg})$ in soil irrigated for 60 days with DE during the present study.

In present study, the results of paired two sample t-test for metals ( $\mathrm{Zn}, \mathrm{Fe}, \mathrm{Ni}$, Crand $\mathrm{Cd}$ ) revealed that the concentrations of $\mathrm{Zn}, \mathrm{Fe}$ and $\mathrm{Ni}$ were significantly $(\mathrm{P}<0.05)$ higher in $\mathrm{DE}$ irrigated soil than that observed in BWW irrigated soil, while the concentrations of $\mathrm{Cr}$ and $\mathrm{Cd}$ were insignificantly $(\mathrm{P}>0.05)$ higher in $\mathrm{DE}$ irrigated soil. It was also observed that the DE irrigation increased the amount of heavy metals such as $\mathrm{Zn}$, Ni and Fe in the soil (Table 1). The Pearson's correlation at $5 \%$ level between physicochemical parameters and heavy metals in DE irrigated soil indicated that OC$\mathrm{pH}, \mathrm{K}-\mathrm{pH}, \mathrm{Zn}-\mathrm{pH}, \mathrm{Cr}-\mathrm{pH}, \mathrm{P}-\mathrm{EC}, \mathrm{Fe}-\mathrm{EC}, \mathrm{TKN}-\mathrm{OC}, \mathrm{Zn}$ $-\mathrm{K}, \mathrm{Cd}-\mathrm{TKN}, \mathrm{Ni}-\mathrm{Fe}, \mathrm{Cd}-\mathrm{Ni}$ had a strong positive correlation (Table 2).

Heavy metal contents in roots and leaves of $S$. oleracea: The metal contents in leaves and roots of $S$. oleracea are indicated in Table 3.Among various heavy metals, the concentrations of $\mathrm{Ni}(36.99 \pm 2.39 /$ $66.47 \pm 3.65 \mathrm{mg} / \mathrm{kg}), \mathrm{Cr}(21.62 \pm 0.83 / 54.19 \pm 8.39 \mathrm{mg} / \mathrm{kg})$ and $\mathrm{Cd}(6.47 \pm 0.74 / 7.73 \pm 1.41 \mathrm{mg} / \mathrm{kg})$ in roots/leaves were found to be above the permissible limits except in 
case of Zn which was higher only in leaf part of $S$. oleracea than the permissible limits of FAO/WHO standard, Codex Alimentarious Commission (1984) and Indian standards (Awashthi, 2000).

The present study revealed that heavy metal content of $\mathrm{Zn}(78.95 \pm 7.59 \mathrm{mg} / \mathrm{kg})$ and $\mathrm{Fe}(353.24 \pm 7.94 \mathrm{mg} / \mathrm{kg})$ in leaves of $S$. oleracea irrigated with DE were found higher than the $\mathrm{Zn}(33.1 \pm 1.9 \mathrm{mg} / \mathrm{kg})$ and $\mathrm{Fe}(309 \pm 27.0$ $\mathrm{mg} / \mathrm{kg}$ ) in leaves of $S$. oleracea irrigated with waste water recorded by (Arora et al. 2008). Similarly, the concentrations of $\mathrm{Zn} \quad(78.95 \pm 7.59 \mathrm{mg} / \mathrm{kg}), \quad \mathrm{Cr}$ $(21.62 \pm 0.83 \mathrm{mg} / \mathrm{kg})$ and $\mathrm{Cd}(6.47 \pm 0.74 \mathrm{mg} / \mathrm{kg})$ were recorded to be higher in leaves of $S$. oleracea than $\mathrm{Zn}$ $(62.24 \mathrm{mg} / \mathrm{kg}), \mathrm{Cr}(4.08 \mathrm{mg} / \mathrm{kg}), \mathrm{Cd}(0.39 \mathrm{mg} / \mathrm{kg})$ present in leaves of spinach grown in waste water irrigated soil of Varanasi reported by Mishra and Tripathi (2008).

Earlier studies by Chandra et al. (2009) recorded the lower concentrations of heavy metals such as $\mathrm{Zn}$ $(21.04 \pm 3.76 \mathrm{mg} / \mathrm{kg}), \mathrm{Fe}(340.08 \pm 12.36 \mathrm{mg} / \mathrm{kg}), \mathrm{Ni}$ $(16.80 \pm 2.08 \mathrm{mg} / \mathrm{kg})$, and $\mathrm{Cd}(2.18 \pm 0.56 \mathrm{mg} / \mathrm{kg})$ except $\mathrm{Cr}(50.62 \pm 4.20 \mathrm{mg} / \mathrm{kg})$ in leaves of wheat plant, while $\mathrm{Zn}-48.24 \pm 2.86 \mathrm{mg} / \mathrm{kg}$, , Ni- $3.16 \pm 0.53 \mathrm{mg} / \mathrm{kg}, \mathrm{Cr}-$ $15.76 \pm 2.08 \mathrm{mg} / \mathrm{kg}$, and $\mathrm{Cd}-2.04 \pm 0.43 \mathrm{mg} / \mathrm{kg}$ except $\mathrm{Fe}-560.46 \pm 13.48 \mathrm{mg} / \mathrm{kg}$ in leaves of mustard plant grown in DE and tannery mixed effluent irrigated soil at Unnao (U.P.), India as compared with the heavy metals in leaves of $S$. oleracea. However the present value of $\mathrm{Zn}(78.95 \pm 7.59) \mathrm{mg} / \mathrm{kg}$ and $\mathrm{Fe}(340.08 \pm 12.36$ $\mathrm{mg} / \mathrm{kg}$ ) in leaves were lower than that observed for $\mathrm{Zn}$ $(297.40 \mathrm{mg} / \mathrm{kg})$ and $\mathrm{Fe}(509.40 \mathrm{mg} / \mathrm{kg})$ in Spinach irrigated with waste water in the area Shahre Rey, Iran reported by Bigdelhi and Seilsepour (2008).

The content of $\mathrm{Zn}(34.55 \pm 5.58 \mathrm{mg} / \mathrm{kg}), \mathrm{Cr}(54.19 \pm 8.39$ $\mathrm{mg} / \mathrm{kg})$ and $\mathrm{Cd}(7.73 \pm 1.41 \mathrm{mg} / \mathrm{kg})$ in root of $S$. oleracea irrigated with DE were found higher than the $\mathrm{Zn}(0.781 \pm 0.02 \mathrm{mg} / \mathrm{kg}), \mathrm{Cr}(0.511 \pm 0.04 \mathrm{mg} / \mathrm{kg})$ and $(\mathrm{Cd}-0.052 \pm 0.003 \mathrm{mg} / \mathrm{kg})$ in root of Spinach grown in the vicinity of an industrial area Faisalabad, Pakistan. Whereas, the concentration of $\mathrm{Zn}, \mathrm{Fe}, \mathrm{Ni}, \mathrm{Cr}$, and $\mathrm{Cd}$ in the root part of $S$. oleracea were recorded to be higher than the concentration of Zn- $18.26 \pm 2.24 \mathrm{mg} / \mathrm{kg}$, $\mathrm{Fe}-128.36 \pm 10.86 \mathrm{mg} / \mathrm{kg}, \mathrm{Ni}-5.14 \pm 1.02 \mathrm{mg} / \mathrm{kg}, \mathrm{Cr}-$ $10.16 \pm 2.05 \mathrm{mg} / \mathrm{kg}$, and Cd-2.12 $\pm 0.34 \mathrm{mg} / \mathrm{kg}$ in root of wheat plant and $\mathrm{Zn}-61.26 \pm 4.06 \mathrm{mg} / \mathrm{kg}$, Ni- $7.28 \pm 1.16$ $\mathrm{mg} / \mathrm{kg}, \mathrm{Cd}-2.26 \pm 0.16 \mathrm{mg} / \mathrm{kg}$ except $\mathrm{Fe}-432.57 \pm 7.06$ $\mathrm{mg} / \mathrm{kg}, \mathrm{Cr}-60.26 \pm 4.16 \mathrm{mg} / \mathrm{kg}$ in root of mustard plant grown in DE and tannery mixed effluent irrigated soil at Unnao (U.P.), India.

The $\mathrm{t}$-test showed that the contents of metals were increased significantly $(\mathrm{P}<0.05)$ for the $\mathrm{Zn}, \mathrm{Fe}$ and $\mathrm{Ni}$ in both leaves/roots, while $\mathrm{Cr}$ was significantly $(\mathrm{P}<0.05)$ increased only in roots and $\mathrm{Cd}$ in leaves parts of $S$. oleracea (Table 3).

Accumulation and transfer of metals from soil to $S$. oleracea: Soil-to-plant transfer is one of the key components ofhuman exposure to metals through foodchain. The ratio of metals between soil and plants 
Table 3. Heavy metal contents $(\mathrm{mg} / \mathrm{kg}$ ) for S. oleracea grown in BWW and DE irrigated soil.

\begin{tabular}{llcccc}
\hline \hline Metals & Parts & BWW irrigated & DE irrigated & $\begin{array}{c}\text { Permissible } \\
\text { limits (a) }\end{array}$ & $\begin{array}{c}\text { Permissible } \\
\text { limits (b) }\end{array}$ \\
\hline $\mathrm{Zn}$ & Leaves & $40.63 \pm 4.53$ & $78.95 \pm 7.59^{*}$ & 60 & 50 \\
& Root & $24.18 \pm 4.04$ & $34.55 \pm 5.58^{*}$ & & - \\
$\mathrm{Fe}$ & Leaves & $169.52 \pm 3.49$ & $353.24 \pm 7.94^{*}$ & 450 & 1.5 \\
$\mathrm{Ni}$ & Root & $139.98 \pm 7.47$ & $334.12 \pm 7.14^{*}$ & & 20 \\
& Leaves & $30.96 \pm 2.86$ & $36.99 \pm 2.39^{*}$ & 20 & \\
$\mathrm{Cr}$ & Root & $35.24 \pm 6.08$ & $66.47 \pm 3.65^{*}$ & & 5 \\
& Leaves & $20.57 \pm 1.79$ & $21.62 \pm 0.83$ & 5 & 1.5 \\
$\mathrm{Cd}$ & Root & $27.66 \pm 7.71$ & $54.19 \pm 8.39^{*}$ & & \\
& Leaves & $3.52 \pm 0.56$ & $6.47 \pm 0.74^{*}$ & 0.3 & \\
\hline
\end{tabular}

Source (a) FAO/WHO standard (Codex Alimentarious Commission, 1984), Source (b) Indian standard (Awashthi, 2000), *indicates significant increase $(\mathrm{P}<05)$.

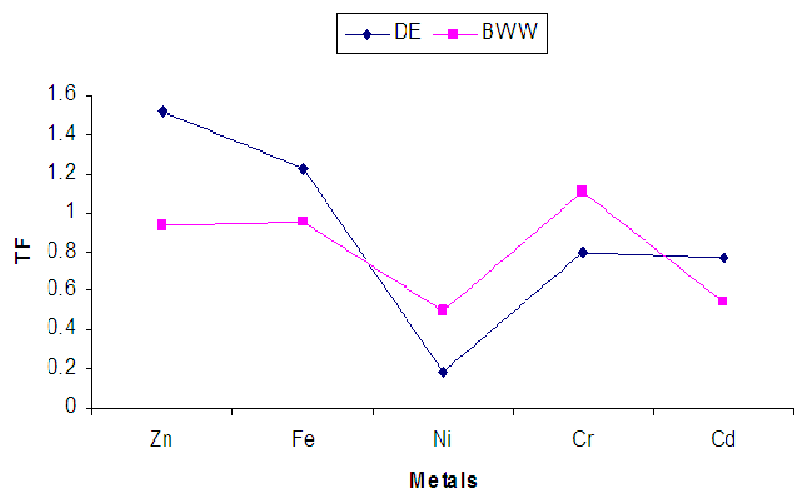

Fig. 1. TF for S. oleracea grown in DE irrigated soil.

is an important criterion for the selection of crop plants for the cultivation in soils contaminated with high level of toxic metals (Bose et al., 2008).

In the present study $\mathrm{TF}$ values for $\mathrm{Zn}(1.51)$ and $\mathrm{Fe}$ (1.23) were usually higher than those for $\mathrm{Ni}(0.18), \mathrm{Cr}$ (0.80) and $\mathrm{Cd}(0.77)$ in $S$. oleracea grown in DE irrigated soil (Fig. 1). The present TF values of $\mathrm{Zn}$ and $\mathrm{Cr}$ were higher than that for $\mathrm{Zn}(0.660), \mathrm{Cr}(0.194)$ while the values of $\mathrm{Ni}$ and $\mathrm{Cd}$ were lower than that observed for $\mathrm{Ni}$ (0.827), $\mathrm{Cd}$ (0.996) in Spinach grown at wastewater irrigated soil (Singh et al., 2010). Among all the metals, TF of $\mathrm{Zn}$ and Fe were higher than other metals indicating their more mobility than other metals. The BCF values were found for $\mathrm{Zn}(0.66)$, Fe (1.16), $\mathrm{Ni}$ (0.32), $\mathrm{Cr}$ (2.00) and $\mathrm{Cd}(0.91)$ in $S$. oleracea grown in DE irrigated soil (Fig.2).

Both BCF and TF have been used to estimate a plant's potential for phytoremediation purpose (Yoon et al., 2006). The ratio of metals between soil and plants is an important criterion for the selection of crop plants for the cultivation on soils contaminated with high level of toxic metals (Bose et al., 2008). Variations in TF among different vegetables may be attributed to differences in the concentration of metals in the soil and the differences in element uptake by different vegetables (Cui et al., 2004; Zheng et al., 2007, Singh

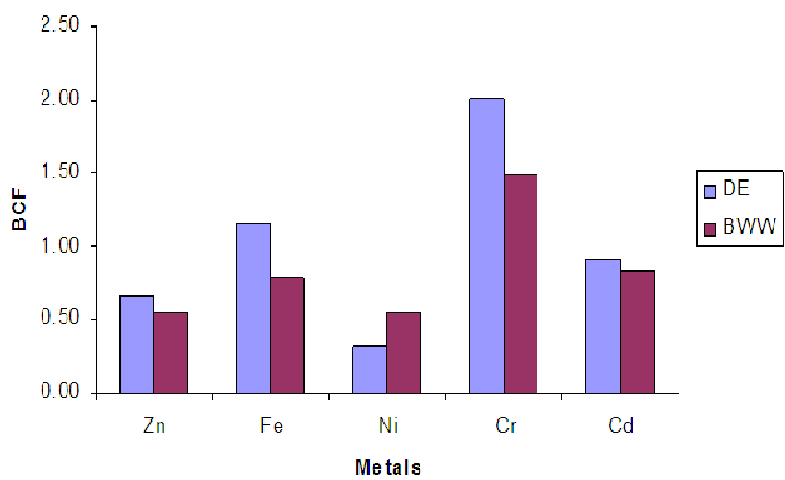

Fig. 2. BCF for $S$. oleracea grown in DE and BWW irrigated soil.

et al., 2010).

\section{Conclusion}

The study concluded that the DE irrigation increased the EC, OC, K, TKN, and $\mathrm{P}$ and decreased the $\mathrm{pH}$ of the soil. The EC and $\mathrm{K}$ values were recorded manifold higher in comparison to other TKN, OC, and P. The $\mathrm{DE}$ irrigation improved the soil nutrient status. However, the higher concentration of heavy metals such as $\mathrm{Ni}, \mathrm{Cd}$ and $\mathrm{Cr}$ in the soil irrigated with $\mathrm{DE}$ may lead to toxicity of soil. In $S$. oleracea grown in $\mathrm{DE}$ irrigated soil, there was an increase of $\mathrm{Zn}, \mathrm{Fe}, \mathrm{Cr}$ concentration in leaves and that of $\mathrm{Ni}$ and $\mathrm{Cd}$ in root. $\mathrm{BCF}$ and TF values of $\mathrm{Zn}, \mathrm{Cr}, \mathrm{Fe}$ more than one showed high mobility affinity of these metals being transferred from roots to leaves resulting in their greater accumulation and thus capable tolerate higher levels of $\mathrm{Zn}, \mathrm{Cr}$ and $\mathrm{Fe}$.

It is suggested that these effluents should be properly diluted prior to discharge from industries to bring down the metals concentration well within the prescribed limits to maintain soil health for irrigation purposes for the maximum yield of this crop and also to avoid risk for the accumulation of toxic metals in edible parts of the crop. 


\section{ACKNOWLEDGEMENT}

The University Grant Commission, New Delhi, India is acknowledged for providing the financial support in the form of UGC research fellowship (F.7-70/2007 BSR) to Mr. Chakresh Pathak.

\section{REFERENCES}

Abbas, S.T., Sarfras, M., Mehdi, S.M., Hassan, G. and Rehman, O.U. (2007). Trace element accumulation in soil and rice plants irrigated with the contaminated water. Soil Tillage Res., 94: 503-509.

APHA (2005).Standard methods for the examination of water and wastewater (21st Edn.). Washington, D.C.: American Public Health Association.

Arora, M., Kiran, B. Rani, S. Rani, A. Kaur, B. and Mittal, N. (2008). Heavy metal accumulation in vegetables irrigated with water from different sources. Food Chemistry, 111: 811-815.

Awashthi, S.K. (2000). Prevention of Food Adulteration Act No. 37 of 1954. Central and State rules as amended for 1999, 3rd ed. Ashoka Law House, New Delhi

Chandra, R., Kumar, P.K., Singh, J. (2004). Impact of an aerobically treated and untreated (raw) distillery effluent irrigation on soil micro flora, growth, total chlorophyll and protein contents of Phaseolus aureus $\mathrm{L}$. J. Environ. Biol., 25:381-385.

Bigdeli, M. and Seilsepour, M. (2008). Investigation of metals accumulation in some vegetables irrigated with waste water in Shahre Rey-Iran and toxicological implications. American - Eurasian Journal of Agriculture \& Environment Science, 4(1): 86-92.

Bakircioglu, D., Kurtulus, Y. B. and Ucar, G. (2011). Determination of some traces metal levels in cheese samples packaged in plastic and tin containers by ICP-OES after dry wet and microwave digestion. Food and Chemical Toxicology, 49: 202-207.

Bose, S. and Bhattacharyya, A.K. (2008). Heavy metal accumulation in wheat plant grown in soil amended with industrial sludge. Chemosphere, 70: 1264-1272.

Chandra, R., Bharagava, R.N., Yadav, S. and Mohan, D. (2009) Accumulation and distribution of toxic metals in wheat (TriticumaestivumL.) and Indian mustard (Brassica campestrisL.) irrigated with distillery and tannery effluents. Journal of Hazardous Materials, 162: 1514-1521.

Chandraju, S., Chidankumar, C. S. and Venkatachalapathy, R. (2010). Irrigational impact of distillery spentwash on the growth, yield and nutrients of leafy vegetables. Bioresearch Bulletin, 2: 83-90 83.

Charman, P.E.V., and Murphy, B.W. (1991).Soils-their properties and management. A soil conservation handbook for New South Wales. Sydney: Sydney University PresslSoil Conservation Service, NSW.

Chaturvedi, R.K. and Sankar, K. (2006). Laboratory manual for the physico-chemical analysis of soil, water and plant. Dehradun: Wildlife Institute of India.

Codex Alimentarious Commission (1984). Contaminants, joint $\mathrm{FAO} / \mathrm{WHO}$ food standards program, vol. XVII, 1st ed. Geneva: Codex Alimentarious.

Cui, Y.J., Zhu, Y.G., Zhai, R.H., Chen, D.Y. Huang, Y.Z., Qui, Y. and Liang, J.Z. (2004). Transfer of metals from near a smelter in Nanning, China. Environmental International, 30: 785-791.
Farooq, M., Anwar, F. and Rashid, U. (2008). Appraisal of heavy metal contents in different vegetables grown in the vicinity of an industrial area. Pakistan Journal of Botany, 40(5): 2099-2106.

Gupta, A.K., Sinha, S., Basant, A. and Singh, K. P. (2007). Multivariate analysis of selected metals in agricultural soil receiving UASB treated tannery effluent at Jajmau, Kanpur (India). Bulletin of Environmental Contamination Toxicology, 79: 577-582.

Jagtap, M. N., Kulkarni, M. V. and Puranik, P. R. (2010). Flux of heavy metals in soils irrigated with urban wastewaters. American-Eurasian J. Agric. and Environ. Sci., 8(5): 487-493.

Kannan, A. and Upreti, R. K. (2008). Influence of distillery effluent on germination and growth of mung bean (Vigna radiata, L.R. Wilczek) seeds. Journal of Hazardous Materials, 53(1-2): 609-615.

Kabata-Pendias, A., Pendias, H., 1992. Trace Elements in Soils and Plants, second ed. CRC Press, Boca Raton, FL, USA.

Kaushik, A., Nisha, R., Jagjeeta, K. and Kaushik, C.P. (2005).Impact of long and short term irrigation of a sodic soil with distillery effluent in combination with bioamendments. Bioresource Technology, 96(17): 1860 -1866 .

Kumar, V. and Chopra, A.K. (2012).Fertigation effect of distillery effluent on agronomical practices of Trigonella foenum-graecum L. (Fenugreek). Environment Monitoring and Assessment, 184: 12071219.

Kumar, P. and Chandra, R. (2004). Detoxification of distillery effluent through Bacillus thuringiensis (MTCC 4714) enhanced phytoremediation potential of Spirodelapolyrrhiza L. Schliden. Bull. Environ. Contam. Toxicol.,73: 903-910.

Malaviya, P. and Sharma, A. (2011): Effect of distillery effluent on yield attributes of Brassica napus L. J. Environmental Biology, 32:385-389.

Mapanda, F., Mangwayana, E.N., Nyamangara, J., Giller, K.E. (2005). The effect of long-term irrigation using wastewater on heavy metal contents of soils under vegetables in Harare, Zimbabwe. Agric. Ecosyst. Environ., 107: 151-165.

Mishra, A., and Tripathi, B.D. (2008). Heavy metal contamination of soil, and bioaccumulation in vegetables irrigated with treated waste water in the tropical city of Varanasi, India. Toxicological \& Environmental Chemistry.doi:10.1080/02772240701 740197.

Nyamangara, J. and Mzezewa, J. (1999). The effects of longterm sewage sludge application on $\mathrm{Zn}, \mathrm{Cu}, \mathrm{Ni}$ and $\mathrm{Pb}$ levels in clay loam soil under pasture grass in Zimbabwe. Agric. Ecosyst. Environ., 73: 199-204.

Patterson, S. J., Chanasyk, D. S., Mapfumo, E., and Naeth, M. A. (2008). Effects of diluted Kraft pulp mill effluent on hybrid poplar and soil chemical properties. Irrigation Science, 26, 547-560.

Pant, D. and Adholeya, A. (2007). Biological approaches for treatment of distillery wastewater: A review. Biores. Technol., 98, 2321-2334

Rattan, R.K., Datta, S.P., Chhonkar, P.K., Suribabu, K., Singh, A.K. (2005).Long-term impact of irrigation with sewage effluents on heavy metal content in soils, crops and groundwater - a case study. Agriculture, Ecosyst. Environ., 109:310-322. 
Srivastava, A. and Chandra, R. (2001). Comparative toxicological evaluation of microbially treated and untreated tannery effluent with Lemna minor. $J$. Ecophysiol. Occup. Hlth., 1: 211-218.

Sharma, R. K., Agrawal, M.and Marshall, F. (2007). Heavy metal contamination of soil and vegetables in suburban areas of Varanasi, India. Ecotoxicology and Environmental Safety, 66: 258-266.

Singh, A., Sharma, R. K., Agrawal, M. and Marshall, F. M. (2010). Risk assessment of heavy metal toxicity through contaminated vegetables from waste water irrigated area of Varanasi, India. Tropical Ecology, 51(2S): 375-387.

Singh,B. and Yadav, Anoop (2012). Effect of distillery effluent on different wheat cultivars. World Journal of Environmental Biosciences, 1 (1): 38-41

Srivastava, S., Chopra, A. K. and Pathak, C. (2012). Ferti-irrigational impact of distillery effluent and Di-ammonium phosphate on the soil and growth characteristics of Egg plant (Solanum melongena L.). Journal of Applied and Natural Science, 4 (2): 275-283

Yargholi, B., Azimi, A. A., Baghvand, A., Liaghat, A.M. and Fardi, G.A. (2008). Investigation of cadmium absorption and accumulation in different parts of some vegetables. American-Eurasian J. Agric. \& Environ. Sci., 3 (3):357-364.

Yuzbas, N., Sezgin, E., Yıldırım, M., Yıldırım, Z. (2003).Survey of lead, cadmium, iron, copper and zinc in kas_archeese.FoodAdd.Contam., 20: 464-469.

Yoon, J., Cao, X., Zhou, Q., Ma, L. Q. (2006). Accumulation of $\mathrm{Pb}, \mathrm{Cu}$, and $\mathrm{Zn}$ in native plants growing on a contaminated Florida site. Science of the Total Environment, 368: 456-464

Zheng, N., Wang, Q.C. and Zheng, D.M. (2007). Health risk of $\mathrm{Hg}, \mathrm{Pb}, \mathrm{Cd}, \mathrm{Zn}$ and $\mathrm{Cu}$ to the inhabitants around Huludao zinc plant in China via consumption of vegetables. Science of the Total Environment, 383: 81-89. 